8-1-2004

\title{
Eliminating Absorbing Interference Using The H-point Standard Addition Method: Case of Griess Assay in The Presence of Interferent Heme Enzymes Such As NOS
}

\author{
Perera N. Indika \\ Cleveland State University \\ Mekki Bayachou \\ Cleveland State University, M.BAYACHOU@csuohio.edu
}

Follow this and additional works at: https://engagedscholarship.csuohio.edu/scichem_facpub

Part of the Chemistry Commons

How does access to this work benefit you? Let us know!

\section{Publisher's Statement}

The final publication is available at Springer via http://dx.doi.org/10.1007/s11661-004-0269-3

\section{Recommended Citation}

Indika, Perera N. and Bayachou, Mekki, "Eliminating Absorbing Interference Using The H-point Standard Addition Method: Case of Griess Assay in The Presence of Interferent Heme Enzymes Such As NOS" (2004). Chemistry Faculty Publications. 312.

https://engagedscholarship.csuohio.edu/scichem_facpub/312

This Article is brought to you for free and open access by the Chemistry Department at EngagedScholarship@CSU. It has been accepted for inclusion in Chemistry Faculty Publications by an authorized administrator of EngagedScholarship@CSU. For more information, please contact library.es@csuohio.edu. 
Perera N. Indika $\cdot$ Mekki Bayachou

\section{Eliminating absorbing interference using the H-point standard addition method: case of Griess assay in the presence of interferent heme enzymes such as NOS}

\begin{abstract}
Standard calibration methods used to determine trace analytes usually yield significant deviations from the actual analyte value in the presence of interferents in the assay media. These deviations become of particular concern when the concentration of the analyte is low, and when the results are used to draw mechanistic or kinetic conclusions, for instance in enzyme structure-function studies. In these circumstances, the H-point standard addition method (HPSAM) provides superior precision and accuracy. This method is developed here for the case of the spectrophotometric Griess assay used to determine nitrite in various enzymology investigations, such as nitrite determination in studies of nitrite reductases $(\mathrm{NiR})$, or when determining nitrite as a breakdown product of nitric oxide synthesized by NOS enzymes. The results obtained by HPSAM are contrasted with those of the traditional calibration method.
\end{abstract}

Keywords Nitrite $\cdot$ Determination $\cdot$ NOS ·

Enzymes $\cdot$ Griess $\cdot$ Assay

\section{Introduction}

Determination of trace amounts of nitrite $\left(\mathrm{NO}_{2}{ }^{-}\right)$is crucial to a number of mechanistic and kinetic investigations addressing the structure-functions of enzymes. Examples include investigations that address the mechanisms and kinetics of the molecular functions of enzymes such as nitrite reductases (NiR) [1], and nitric oxide synthases (NOS) [2]. In the latter case, accurate determination of $\left(\mathrm{NO}_{2}^{-}\right)$as a breakdown product of nitric oxide (NO) is of particular importance to current investigations, which aim to understand the mechanism of function of NOS enzymes. NOS is a class of heme enzymes which catalyze the in vivo synthesis of the effector molecule NO [3]. NO is synthesized through the oxidation of the amino acid L-arginine, and is used in vasodilation, neurotransmission, cytotoxicity, and numerous physiological processes; it is also involved in the development of a host of pathological states [4,5].

In NOS enzymology, NO is often quantified in the form of $\mathrm{NO}_{2}^{-}$, a stable breakdown product of $\mathrm{NO}$ in aerobic reaction media, by using a standard calibration method that uses the Griess assay. This method is one of the most popular and simplest used to spectrophotometrically detect $\mathrm{NO}_{2}{ }^{-}$concentration $[6,7]$. This assay is based on a two-step chemical derivatization reaction, using sulfanilamide and $N$-1-napthylethylenediamine dihydrochloride (NED), and yields an azo-compound with $\lambda_{\max }$ at $540 \mathrm{~nm}$; the latter is used to quantify the $\mathrm{NO}_{2}{ }^{-}$originally present. The Griess assay is widely used to determine $\mathrm{NO}_{2}{ }^{-}$in a variety of biological and experimental matrices, such as plasma, serum, urine and tissue culture media $[8,9]$. However, serious accuracy problems may arise in the presence of absorbing interferences, especially if these are not taken into account during the calibration step.

For instance, an issue of major concern to those using the Griess assay to determine $\mathrm{N}_{2} \mathrm{O}^{-}$in NOS enzymology using standard calibration curves is that the absorption band of NOS-heme as well as that of the flavins around $520-540 \mathrm{~nm}$ in full-length NOS may positively interfere with the absorption reading of the azo-compound, especially when the enzyme is not separated by size exclusion prior to the Griess assay. The same is true for any heme-protein with heme Q-band absorption overlapping with that of the target azo-compound $[10,11]$. Even if the enzyme is separated by size exclusion prior to conducting the assay, trace amounts of protein may remain in the solution and may significantly interfere with the final reading. This is especially critical in the case of 
NOS, since the molar extinction coefficient (at $540 \mathrm{~nm}$ ) of NOS is quite large. Therefore, the traditional standard calibration curve may lead to erroneous quantitation.

An alternative method called standard addition can be used instead. However this method cannot remove the constant error resulting from other absorbing components in the system, although it may remove the error resulting from the sample matrix. To overcome this obstacle a new procedure called the H-point standard addition method (HPSAM) was introduced in 1988 by Bosch-Reig et al $[12,13]$. The method is mainly based on the principle of the dual wavelength spectrophotometer coupled with the standard addition method. Among other advantages of this method is the fact that it eliminates interferences caused by absorbing components intrinsic to the system being analyzed, as well as interference from the blank matrix solution $[14,15,16]$. The method is growing in popularity, and continues to find new applications in a number of fields $[17,18,19$, 20, 21]. A modified version of HPSAM, called generalized HPSAM, can be used to quantify the analyte concentration even when the nature of the interferent is not known [22, 23].

The objective of the present work is to explore the relative error (due to interference) associated with $\mathrm{NO}_{2}{ }^{-}$ determination when performing the traditional standard calibration curve rather than the HPSAM. The performance of the new method is contrasted with that of the traditional calibration, especially when dealing with the very low $\mathrm{NO}_{2}{ }^{-}$concentrations usually involved in enzymatic initial rate determinations or under single turnover conditions.

The method is first developed and validated with myoglobin, a cheap commercially available heme-protein that gives interfering absorption similar to NOS in the 520-540 nm region. Then, determinations of $\mathrm{NO}_{2}{ }^{-}$ in the presence of mouse inducible NOS (iNOS) are conducted to prove the applicability of the new method to the NOS case.

\section{Experimental section}

\section{Reagents}

All the chemicals used were of analytical grade. Nanopure deionized water (specific resistance $>18.2 \Omega \mathrm{cm}$ ) used throughout the experiment was supplied by a Barnstead water purification system. All working solutions of $\mathrm{NO}_{2}{ }^{-}$were prepared using $0.1 \mathrm{M}$ standard $\mathrm{NO}_{2}{ }^{-}$solution. Heme-proteins, Horse Heart myoglobin and mouse inducible NOS, iNOS, were purchased from Sigma-Aldrich. Original concentrations of hemeproteins were quantified using their molar extinction coefficients $\left(163.9 \mathrm{mM}^{-1} \mathrm{~cm}^{-1}\right.$ at $410 \mathrm{~nm}$ for myoglobin [24], and $71 \mathrm{mM}^{-1} \mathrm{~cm}^{-1}$ at $414 \mathrm{~nm}$ for iNOS [25]). The Griess reagent kit was purchased from Promega and was used according to the technical instructions of this supplier.
Apparatus

UV-visible absorbance spectra were recorded on an Agilent 8453 spectrophotometer using 1-cm path UVVis cells. Spectra were collected between 400 and $650 \mathrm{~nm}$. Measurements of $\mathrm{pH}$ were made with an Accumet AB15 pH-meter using a combined glass electrode.

\section{Procedure}

Myoglobin was dissolved in $\mathrm{pH} 7.6$ phosphate buffer $(10 \mathrm{mM})$. This solution was purified by filtration on YM30 membranes (Amicon); its concentration was quantified by measuring its absorbance at $410 \mathrm{~nm}$. Spectra were recorded separately for the azo-compound, for myoglobin, and for iNOS in the region of 450-620 nm (Fig. 1) to obtain the best working wavelengths for HPSAM (see Sect. 3.1, "Selection of wavelengths"). Standard samples containing four different concentrations of $\mathrm{NO}_{2}^{-}(10,7.5, \quad 5.0$ and $2.5 \mu \mathrm{M})$ in the presence of three different concentrations of myoglobin $(10,15$, and $20 \mu \mathrm{M})$ were prepared, giving a total of 12 working standards. The total volume of each sample analyzed was $6.00 \mathrm{ml}$. The range of nitrite concentration in these working samples was selected based on actual ranges used in enzymology studies. Each standard was divided into $6 \times 1.00 \mathrm{ml}$ aliquots. Then known amounts of $\mathrm{NO}_{2}{ }^{-}$ standard were successively added into each vial followed by appropriate amounts of the Griess reagent system (sulfanilamide and NED solutions). The mixtures were incubated for $10 \mathrm{~min}$. The resulting solutions were then diluted twice (to $2 \mathrm{ml}$ ) with deionized water. The $\mathrm{NO}_{2}^{-}$concentration in each standard was then quantified by performing HPSAM (see Sects. 3.2 and 3.4) by measuring the absorbance at two pre-selected wavelengths. Each data point on the graphs is

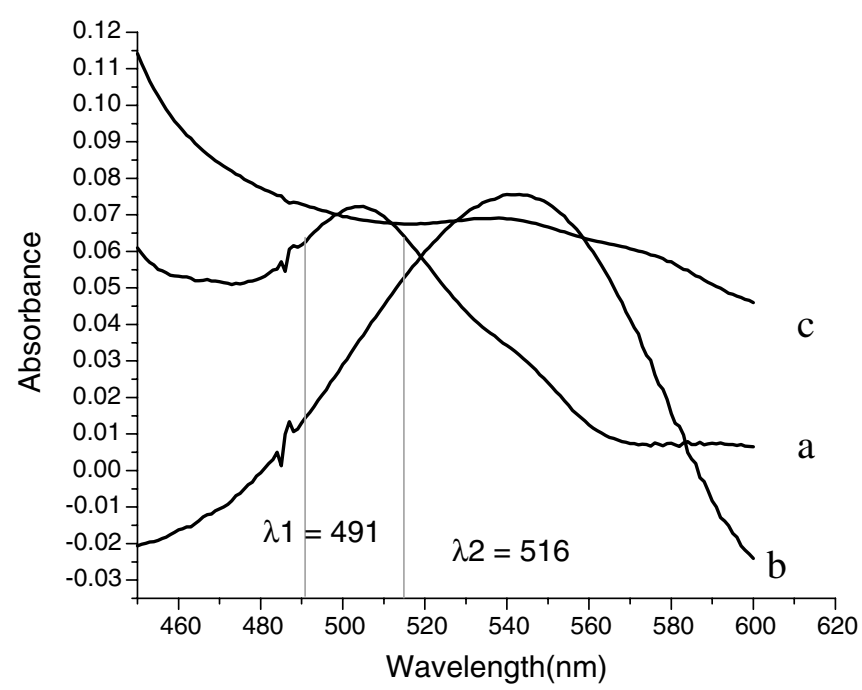

Fig. 1a c Absorbance spectra of a $10 \mu \mathrm{M}$ myoglobin, b azo compound of Griess assay and c $10 \mu \mathrm{M}$ iNOS 
the mean value of results of two separate experiments. For comparison purposes, the $\mathrm{NO}_{2}^{-}$concentration in each sample analyzed by the HPSAM was also quantified using a standard calibration curve constructed at $540 \mathrm{~nm}$. The same procedure was performed with $10 \mu \mathrm{M}$ iNOS as an interferent for three different $\mathrm{NO}_{2}{ }^{-}$concentrations. Determinations of $\mathrm{NO}_{2}{ }^{-}$generated in situ (through the breakdown of NO synthesized in the medium by iNOS enzymes), were also conducted as described above using the two methods.

The procedure for the NOS assay was as follows: $100 \mu \mathrm{l}$ of iNOS $(8 \mu \mathrm{M})$ were added to $1.00 \mathrm{ml}$ of $50 \mathrm{mM}$ HEPES buffer at pH 7.4 containing $0.1 \mathrm{mM}$ NADPH, $1 \mathrm{mM}$ arginine, $12 \mu \mathrm{M}$ tetrahydrobiopterin and $170 \mu \mathrm{M}$ DTT, all pre-warmed at $37{ }^{\circ} \mathrm{C}$ for 15 mins. The NOS reaction was then allowed to proceed for $12 \mathrm{~min}$ at $37^{\circ} \mathrm{C}$. The reaction was quenched after $12 \mathrm{~min}$ by adding $100 \mu \mathrm{l}$ of ice-cold-deionized water into the reaction vessel and then stored in ice for the assay. The content of the reaction vessel was divided into six aliquots of $200 \mu \mathrm{l}$ on which standard addition and calibration methods were carried out as described in the text.

\section{Results and discussion}

This study explores the impact of absorbing interferences on the determination of small amounts of $\mathrm{NO}_{2}{ }^{-}$ using the Griess assay in the presence of interfering heme proteins, and develops a method based on HPSAM to eliminate the effect of absorbing interference(s) (see requirements in electronic supplementary material, Appendix 1 [12]). Figure 1 shows absorbance spectra for the terminal azo-compound used to determine $\mathrm{NO}_{2}{ }^{-}$, in addition to the spectra of the hemeproteins myoglobin and iNOS in the same region.

One can clearly see that when the hemeproteins myoglobin and iNOS are used in a concentration range similar to that used in actual determinations, they give significant overlapping absorbance in the $520-540 \mathrm{~nm}$ range, which is the most desired range of wavelength used to quantify $\mathrm{NO}_{2}{ }^{-}$in the Griess assay. It is therefore expected that the standard calibration method in the presence of these interferences will lead to significant errors.

Optimization of the system

\section{Selection of $\mathrm{pH}$}

The influence of $\mathrm{pH}$ value on the absorbance of the azocompound in the presence of constant interferent concentration was studied. The absorbance was found to be the highest with an assay solution at $\mathrm{pH}$ 7.4. This $\mathrm{pH}$ was then selected as the optimum $\mathrm{pH}$ for all assays, which also turns out to be the $\mathrm{pH}$ value most often used in enzymatic studies.

\section{Selection of wavelengths}

Two wavelengths for each interferent (myoglobin and iNOS) were selected based on their absorbance in order to fulfill the HPSAM requirement. At these selected wavelengths, the absorbance must be linear with the concentrations and the interferent absorbance must remain equal (electronic supplementary material, Appendix 1). Also, the analytical signal obtained from a mixture containing both the analyte and interferent should be equal to the sum of the individual signals of the two components. In addition, good accuracy and precision can be achieved when the difference in the slopes of the two straight lines measured at the two preselected wavelengths $\left(\lambda_{1}\right.$ and $\left.\lambda_{2}\right)$ are large. Taking all of these criteria into account, the wavelengths 491 and $516 \mathrm{~nm}$ were found to be the best pair of wavelengths for myoglobin, while for iNOS, 544 and $554 \mathrm{~nm}$ were selected as the working wavelengths [26]. However, it is important to note that, although very rare, cases may exist where the selection of the working wavelengths may be prohibited by either the complexity of the sample or by the interferent not necessarily being known.

\section{The HPSAM with myoglobin as interferent}

Several working standard samples containing different concentrations of myoglobin were analyzed using the proposed HPSAM. Figure 2 was obtained by plotting the standard addition curves at 516 and $491 \mathrm{~nm}$ for different nitrite concentrations in the presence of $10 \mu \mathrm{M}$ concentration of myoglobin. As described in the experimental section, the standards are diluted two times, and therefore the value at the crossing point of the two lines of each graph (which corresponds to the concentration of $\mathrm{NO}_{2}{ }^{-}$in the standard) should be multiplied by a factor of two to reflect the original concentration in the analyzed sample. As can be seen from Fig. 2, the concentrations found by the HPSAM satisfactorily reproduce the concentrations in the working samples analyzed. It is worth mentioning that these results are obtained using the samples as prepared in the presence of the interferent without pre-separation steps by sizeexclusion membranes. The observed deviations from actual values in the presence of $10 \mu \mathrm{M}$ of myoglobin as interferent are all very small compared to the deviations encountered when using the traditional calibration curves (see Sect. 3.3).

The recovery data in Table 1 shows that, except for the lowest analyte concentration $(2.5 \mu \mathrm{M})$, and only at high interferent concentrations $(15$ and $20 \mu \mathrm{M})$, the HPSAM performs relatively well given the presence of high interferent concentration $(10-20 \mu \mathrm{M})$. Despite the deviations from the values of the standards, the performance of the HPSAM is still superior to the traditional calibration in the same conditions (see Sect. 3.3). While myoglobin is a good mimic for developing and validating the HPSAM for the Griess assay in the presence of 
Fig. 2a d Standard addition curves obtained for a $10 \mu \mathrm{M}$, b $7.5 \mu \mathrm{M}$, c $5.0 \mu \mathrm{M}$, and d $2.5 \mu \mathrm{M}$ concentrations of $\mathrm{NO}^{-}{ }_{2}$ in the presence of $10 \mu \mathrm{M}$ myoglobin as interferent. Top line (filled squares) in each plot corresponds to the absorbance at $516 \mathrm{~nm}$; bottom line (filled triangles) corresponds to the absorbance at $491 \mathrm{~nm}$. Dilution factor for each standard is 2 ; the concentration found for each case is given at the top of the graph
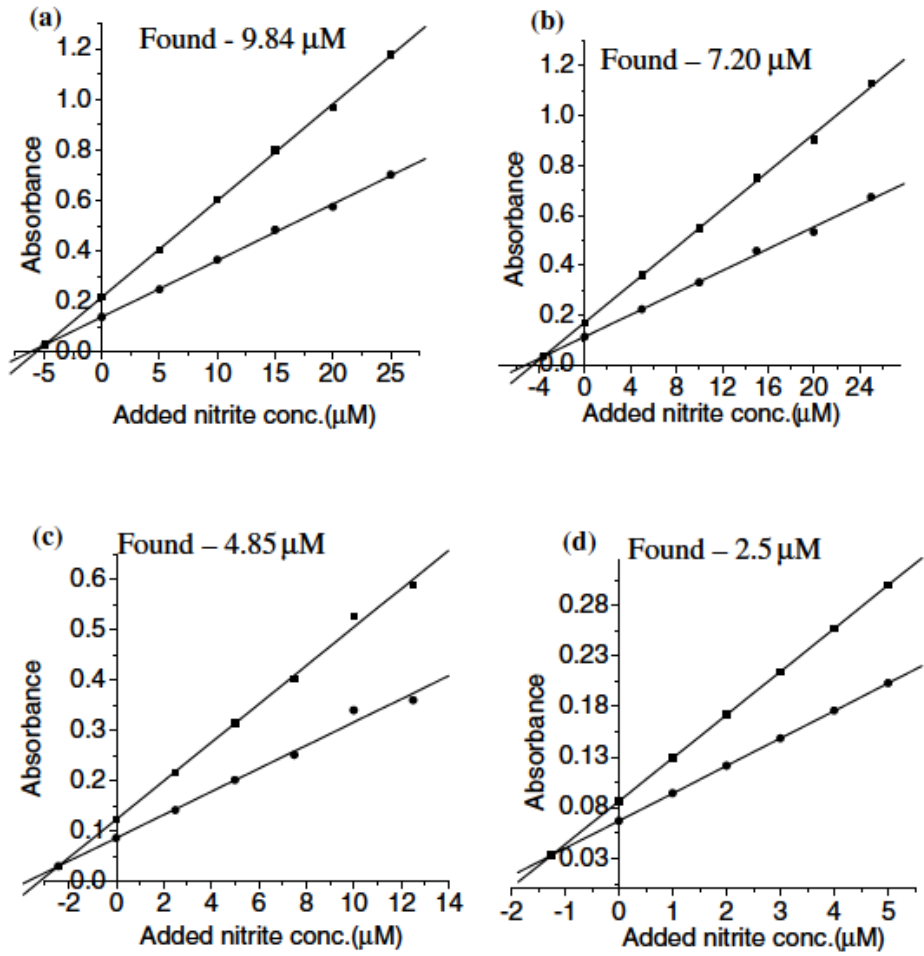

interfering heme-enzymes, its specific chemistry with $\mathrm{NO}_{2}{ }^{-}$ions may interfere. The observed deviations between found and actual values may be due in part to this possible chemical interaction, which may lead to changes in the absorbance at 491 and $516 \mathrm{~nm}$ for myoglobin as interferent; as a requirement for the HPSAM, the absorbance at these pre-selected working wavelengths should be the same as described in the Appendix (supporting info). Even though the concentrations of inteferent used in these validation assays are high, and far beyond possible interferent levels present in actual experiments in the presence of heme enzymes, the HPSAM still seems to be much more reliable than the conventional calibration method often used in enzymology, for instance in NO quantification in the form of $\mathrm{NO}_{2}{ }^{-}$in the presence of NOS heme-enzymes.

Comparison of HPSAM results with those obtained with calibration

To appreciate the accuracy of the HPSAM we compared the performance of this method with that of the traditional calibration in the same conditions. Figure $3 \mathrm{a}$ shows the deviation of obtained $\mathrm{NO}_{2}{ }^{-}$concentrations from actual values using the calibration method in the 2.5-10 $\mu \mathrm{M}$ range of $\mathrm{NO}_{2}{ }^{-}$concentration in the presence of different levels of interfering myoglobin concentrations. A significant discrepancy between obtained and actual nitrite concentration values is clearly observed, especially for higher interferent concentrations and/or when the concentration of $\mathrm{NO}_{2}{ }^{-}$to be determined is low. For instance, as much as $244 \%$ recovery is observed for a $2.5 \mu \mathrm{M} \mathrm{NO}_{2}{ }^{-}$standard in the presence of just $15 \mu \mathrm{M}$ interferent concentration. Divergence from the standard is even worse at higher interferent concentration, see Table 2. While an exhaustive study of the effect of the presence of interferent on the performance of the calibration was not conducted, it is clear that deviations from actual values will be significant for samples with very low $\mathrm{NO}_{2}^{-}$concentration.

The performance of the HPSAM has been tested in the same conditions used for the calibration method. $\mathrm{NO}_{2}{ }^{-}$concentrations obtained by the HPSAM are plotted as a function of actual values in Fig. 3b.

The relative accuracy of the HPSAM over calibration in reproducing $\mathrm{NO}_{2}^{-}$concentrations is remarkable, particularly, if one considers the level of the hemeprotein
Table 1 Summary of recovery data by HPSAM as applied in the Griess assay in the presence of myoglobin as the hemeprotein interferent (at 10,15 and $20 \mu \mathrm{M}$ )

\begin{tabular}{lllll}
\hline \multicolumn{5}{c}{ Recovery data $(\mu \mathrm{M}(\%))$} \\
\hline Nitrite standard $(\mu \mathrm{M})$ & 10 & 7.5 & 5.0 & 2.5 \\
Myogobin interferent at $10 \mu \mathrm{M}$ & $9.84(98.4)$ & $7.20(96)$ & $4.85(97)$ & $2.5(100)$ \\
Myogobin interferent at $15 \mu \mathrm{M}$ & $10.3(103)$ & $7.64(102)$ & $5.10(102)$ & $3.18(127)$ \\
Myogobin interferent at $20 \mu \mathrm{M}$ & $9.20(92)$ & $7.72(103)$ & $5.25(105)$ & $3.46(138)$ \\
\hline
\end{tabular}


Table 2 Summary of recovery data by the conventional calibration as applied in the Griess assay in the presence of myoglobin interferent (at 10,15 and $20 \mu \mathrm{M}$ )

\begin{tabular}{lllll}
\hline \multicolumn{5}{c}{ Recovery Data $(\mu \mathrm{M}(\%))$} \\
\hline Nitrite standard $(\mu \mathrm{M})$ & 10 & 7.5 & 5.0 & 2.5 \\
Myogobin interferent at $10 \mu \mathrm{M}$ & $9.54(95.4)$ & $7.71(103)$ & $5.40(108)$ & $3.73(149)$ \\
Myogobin interferent at $15 \mu \mathrm{M}$ & $12.0(120)$ & $9.5(127)$ & $7.28(146)$ & $6.11(244)$ \\
Myogobin interferent at $20 \mu \mathrm{M}$ & $12.6(126)$ & $10.4(139)$ & $8.8(176)$ & $6.69(268)$ \\
\hline
\end{tabular}

interferent present in the assay. Compare for instance the $100 \%$ recovery for a $2.5-\mu \mathrm{M}$ standard in the presence of $10 \mu \mathrm{M}$ heme protein interferent, to $149 \%$ recovery for the same sample using the traditional calibration curve. The HPSAM eliminates or significantly minimizes the
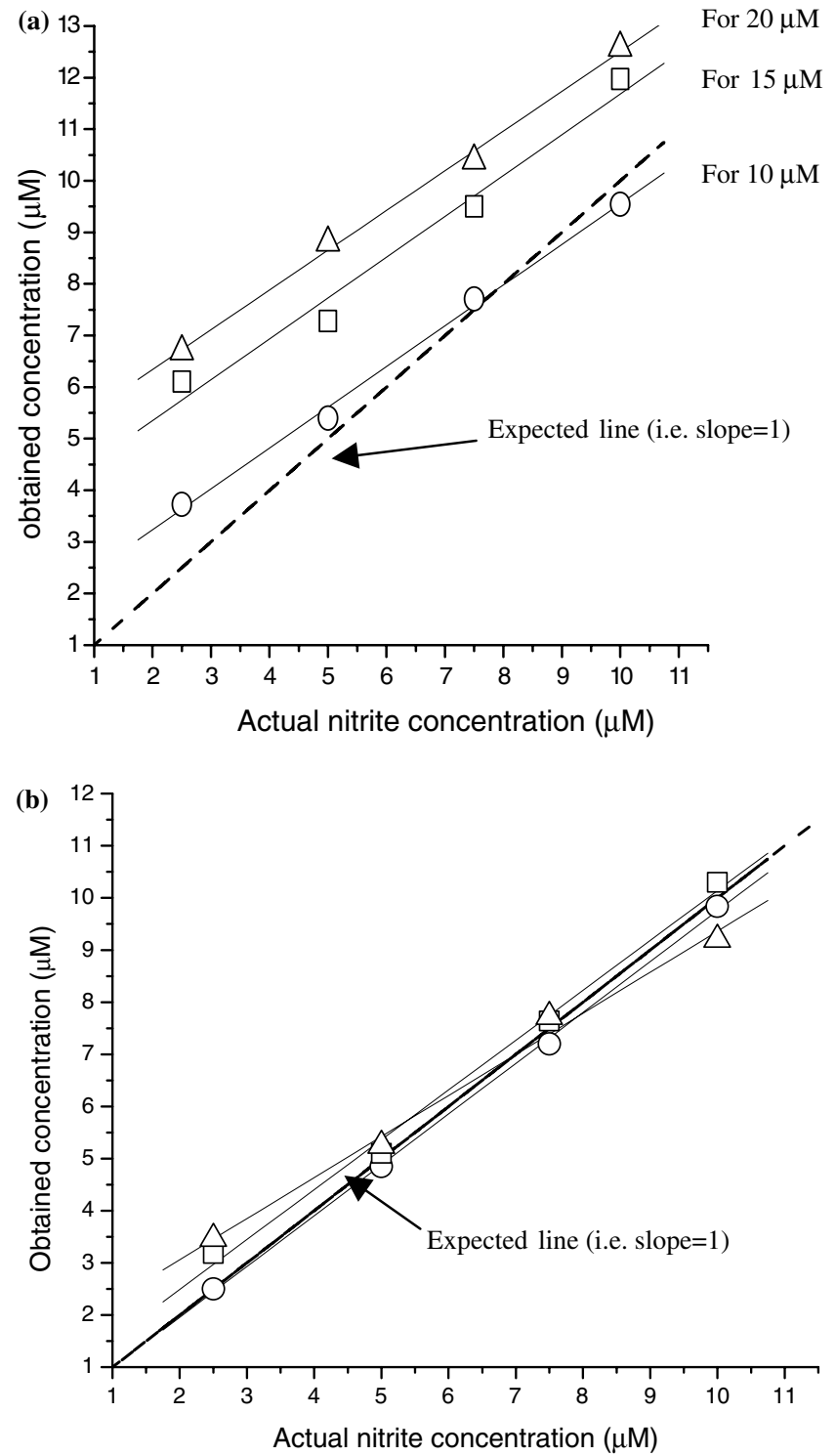

Fig. 3a, b Comparison of obtained and actual nitrite concentration values using a the traditional calibration method at $540 \mathrm{~nm}$ and b the new HPSAM. Three different (interferent) myoglobin concen trations were used: (open circles) $10 \mu \mathrm{M}$, (open squares) $15 \mu \mathrm{M}$, and (open triangles) $20 \mu \mathrm{M}$. The dashed line has a slope of unity and represents the target expected values effect of absorbing interferent. Although there are some slight deviations (like $127 \%$ recovery for $2.5 \mu \mathrm{M}$ standard in the presence of $15 \mu \mathrm{M}$ interferent) observed with the HPSAM determinations at low $\mathrm{NO}_{2}{ }^{-}$concentrations $(2.5 \mu \mathrm{M})$, the method is still far more reliable than a blind calibration in the presence of absorbing interference.

The HPSAM in the case of iNOS as interferent

The proposed method was tested with samples containing different $\mathrm{NO}_{2}{ }^{-}$concentrations in the presence of $10 \mu \mathrm{M}$ iNOS as the absorbing interferent. Again, Figure $4 \mathrm{a}$ shows that the traditional calibration method cannot be used in this assay to accurately determine the concentration of $\mathrm{NO}_{2}{ }^{-}$, particularly, when using this information to derive mechanistic and/or kinetic conclusions (like in mechanistic/kinetic studies of the molecular function of NOS enzymes, where the end product, $\mathrm{NO}$, is determined in the form of $\mathrm{NO}_{2}{ }^{-}$ions using the Griess assay). As shown previously, the deviation from actual values increases as $\mathrm{NO}_{2}{ }^{-}$concentration decreases; in fact, a deviation of $101 \%$ from the actual value was recorded with the calibration curve when the $\mathrm{NO}_{2}{ }^{-}$concentration is $2.5 \mu \mathrm{M}$ in the presence of $10 \mu \mathrm{M}$ iNOS interferent. This discrepancy between measured and actual concentrations values in the presence of iNOS interferent observed in the calibration almost disappears when using the HPSAM. Figure $4 \mathrm{~b}$ shows $\mathrm{NO}_{2}{ }^{-}$concentration values obtained by the proposed HPSAM as a function of actual values in the presence of $10 \mu \mathrm{M}$ iNOS as interferent.

Except for the low end of the nitrite $(2.5 \mu \mathrm{M})$ where a deviation is observed, $\mathrm{NO}_{2}{ }^{-}$concentration values measured in these conditions using the HPSAM are very close to the actual values. Even for the low range of $\mathrm{NO}_{2}{ }^{-}$concentration $(2.5 \mu \mathrm{M})$, the performance of the HPSAM (24\% deviation) is still superior to that of the traditional calibration method (101\% deviation).

Comparison of the performance of HPSAM and standard calibration in actual NOS reactions

Assays for mouse inducible NOS were experimentally performed for 12 min under the conditions given in the enzyme kit. $\mathrm{NO}$ (in the form of $\mathrm{NO}_{2}{ }^{-}$) generated after the catalytic oxidation of the substrate arginine was then quantified using the proposed HPSAM and standard calibration methods. The values of $\mathrm{NO}_{2}{ }^{-}$concentration 

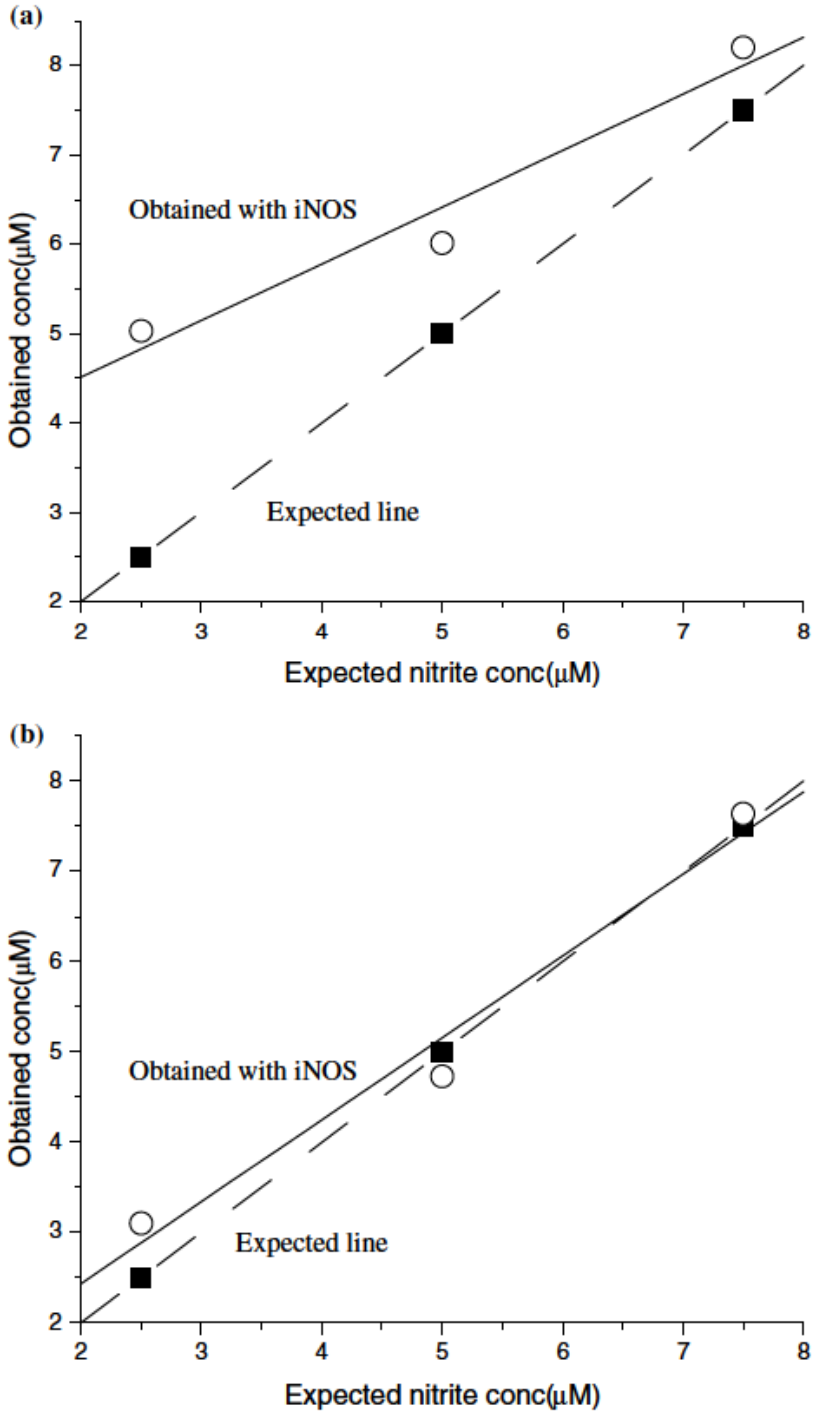

Fig. 4 Comparison of obtained and actual concentration values for results for a the traditional calibration method (at $540 \mathrm{~nm}$ ) and b for HPSAM, in the presence of $10 \mu \mathrm{M}$ iNOS as interferent

for the two methods are shown in Table 3, and are to be compared with the calculated concentration value based on the number of enzyme units (activity) provided by the supplier.

The results clearly show that the performance of HPSAM in the Griess assay case in actual NOS reaction and in the presence of this heme enzyme is superior to that of the traditional calibration method in the same conditions.

Table 3 Nitrite determination by HPSAM and by calibration as applied in the Griess assay in actual NOS reactions

Nitrite concentration HPSAM method Standard calibration based on enzyme units $(\mu \mathrm{M}( \pm \mathrm{SD})) \quad$ method $(\mu \mathrm{M}( \pm \mathrm{SD}))$ used $(\mu \mathrm{M})$

\begin{tabular}{lll}
\hline 5 & $4.31( \pm 0.17)$ & $7.21( \pm 0.22)$ \\
\hline
\end{tabular}

Table 4 Nitrite determination by HPSAM and by calibration as applied in the Griess assay in controls (in other words, zero turn over in absence of NADPH) in the presence of a known amount of $\mathrm{NO}^{-}{ }_{2}$

\begin{tabular}{lll}
\hline $\begin{array}{l}\text { Added } \mathrm{NO}^{-} \\
\text {concentration }(\mu \mathrm{M}) \\
\text { with zero turnover }\end{array}$ & $\begin{array}{l}\text { HPSAM method } \\
(\mu \mathrm{M}( \pm \mathrm{SD}))\end{array}$ & $\begin{array}{l}\text { Calibration } \\
\text { method }(\mu \mathrm{M}( \pm \mathrm{SD}))\end{array}$ \\
\hline 5.0 & $5.1( \pm 0.34)$ & $6.95( \pm 0.25)$ \\
4.3 & 4.22 & 6.83 \\
\hline
\end{tabular}

Although small, the deviation from the calculated concentration may be due to the uncertainty in the values of the enzyme unit number of the sample used (the enzyme activity as determined by the supplier prior to shipping). In this regard, control experiments were run in the absence of NADPH (source of electrons, so no enzyme turnover in its absence), but in the presence of known concentrations of nitrite standard. The Griess assay was then used to determine the $\mathrm{NO}_{2}^{-}$concentration in the two methods for comparison. The results of these assays are shown in Table 4.

These control experiments clearly demonstrate that the HPSAM, as developed here for the Griess assay in conditions similar to NOS assays, satisfactorily reproduces the amount of $\mathrm{NO}_{2}^{-}$present (in the $5 \mu \mathrm{M}$ range), while the traditional calibration method performs poorly. The concentrations found by HPSAM are very close to the known added $\mathrm{NO}_{2}{ }^{-}$amount in the assay medium. This tends to confirm that the slight deviation (Table 3) from the calculated value based on the enzyme units used in the actual enzyme turnover may indeed be due to the uncertainty in the enzyme activity (unit number) of the batch used in this study.

\section{Conclusion}

In this study, the HPSAM is introduced and developed for the case of the Griess assay, used to determine $\mathrm{NO}_{2}{ }^{-}$ concentration in a number of enzymology investigations. This assay may yield significant discrepancy between actual and found concentration values, particularly in the presence of absorbing interferents such as heme/flavoproteins. The HPSAM significantly minimizes, if not eliminates, the effects of this type of absorbing interference and faithfully reproduces the concentration of $\mathrm{NO}_{2}{ }^{-}$even in the presence of relatively high interferent concentrations. The method would be suitable for $\mathrm{NO}_{2}{ }^{-}$determinations in mechanistic/kinetic investigations that address the function of flavo/heme enzymes, where a pre-separation step for the enzyme/ protein would not be necessary.

Acknowledgments This work was supported by a BGIA grant from the American Heart Association (Ohio Valey), and by Startup funds from Cleveland State University. 


\section{References}

1. Zhang Z, Naughton D, Winyard PG, Benjamin N, Blake DR, Symons MCR (1998) Biochem Biophys Res Comm 249:767 772

2. Alderton WK, Cooper CE, Knowles RG (2001) Biochem J 357:593 (and references therein)

3. Witteveen FB, Stuehr DJ, Kaufman S, Gachhui RY, Giovanelli MB (1998) J Biochem Biophys Res Comm 250:36 42

4. Chen Y, Panda K, Stuehr DJ (2002) Biochemistry 41:4618 4625

5. Marletta MA, Hurshman AR, Rusche KM (1998) Curr Opin Chem Biol 2:656 663

6. Bergamini S, Rota C, Canali R, Staffieri M, Daneri F, Bini A, Giovannini F, Tomasi A, Iannone A (2001) Nitric Oxide Biol Ch 5:349 360

7. Stuehr DJ, Huang L, Boggs S (2000) Biochemistry 39:2332 2339

8. Dawson TM, Dawson VL (1995) Neuroscientist 1:7

9. Bredt DS, Snyder SH (1994) Annu Rev Biochem 63:175

10. Bayachou M, Lin R, Cho W, Farmer PJ (1998) J Am Chem Soc 120:9888

11. Burgess JD, Rhoten MC, Hawkridge FM (1998) J Am Chem Soc $120: 4488$

12. Bosch Reig F, Campíns Falcó P (1988) Analyst 113:1011
13. Campíns Falcó P, Verdú Andrés J, Bosch Reig F (1995) Anal Chim Acta 315:267 278

14. Safavi A, Abdollahi H (2001) Talanta 54:727 734

15. Abbaspour A, Baramakeh L (2001) Anal Chim Acta 436:325 331

16. Abdollahi H (2001) Anal Chim Acta 442:327 336

17. Abdollahi H, Zolgharnein J, Azimi GH, Jafarifar D (2003) Talanta 59:1141

18. Zolgharnein J, Abdollahi H, Azimi GH, Jafarifar D (2002) Talanta 57:1067

19. Afkhami A, Zarei AR (2003) Talanta 60:63 71

20. Campins Falco P, Bosch Reig F, Gomez FB (1998) Talanta 47:193 202

21. Sabry SM, Khamis EF (2000) Talanta 51:1219 1231

22. Tortajada Genaro LA, Campins Falco P, Blasco Gomez F, Bosh Reig F (2000) Analyst 125:777 782

23. Tortajada Genaro LA, Campins Falco P, Bosch Reig F, Blasco Gomez F (2000) Analyst 125:771 776

24. Millar SJ, Moss BW, Stevenson MH (1996) Meat Sci 42:277 288

25. Marletta MA, Hurshman AR (2002) Biochemistry 41(10):3439 3456

26. As suggested by one of the reviewers, the method can also work as a multivariate method through the selection of several pairs of wavelengths fulfilling HPSAM requirements (see [12]) 